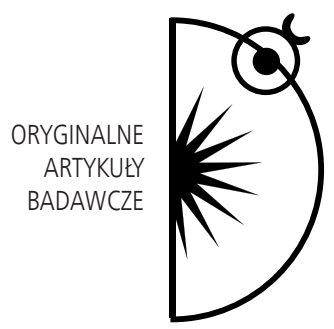

Dorota Pankowska

\title{
Nauczyciele wobec wiedzy o ukrytym programie szkoły
}

DOI: http://dx.doi.org/10.12775/PBE.2013.010

Wydawałoby się, że pojęcie ukrytego programu szkoły straciło swój sens w sytuacji, gdy wiedza o tym, co „szkoła czyni (wpaja, uczy, daje) młodym ludziom do niej uczęszczającym, mimo że to »coś« wcale nie zostało zaplanowane" (Janowski, 1989, s. 63), w polskiej literaturze pedagogicznej funkcjonująca od ponad 20 lat (Janowski, 1989; Meighan, 1993; Żłobicki, 2002), stała się inspiracją wielu badań empirycznych (Pankowska, 2006) i powinna należeć do kanonu przygotowania zawodowego pedagogów i nauczycieli. Okazuje się jednak, że dla wielu pracujących nauczycieli interpretowanie rzeczywistości edukacyjnej z perspektywy krytycznej socjologii edukacji, która nadaje nowy sens „naturalnym i oczywistym” aspektom funkcjonowania szkoły i systemu oświatowego, nadal jest obce. Przekonałam się o tym, prowadząc szkolenie dla nauczycieli (na jesieni 2011 r.) w ramach szerszego projektu mającego na celu doskonalenie praktyk pedagogicznych na jednym z wydziałów Uniwersytetu Marii Curie-Skłodowskiej w Lublinie. Reakcje uczestników zajęć na treści związane z ukrytym programem szkoły były na tyle zaskakujące i odmienne od ich odbioru przez studentów, że skłoniły mnie do przeprowadzenia bardziej systematycznej analizy.

Celem tego artykułu jest ukazanie efektów konfrontacji dotychczasowych doświadczeń i podejścia nauczycieli do swojego miejsca pracy ze spojrzeniem na szkołę z odmiennej perspektywy. 


\section{Założenia metodologiczne i przebieg badań}

Wśród wielu modułów cyklu szkoleń rozwijających kompetencje dydaktyczno-wychowawcze nauczycieli znalazł się 5-godzinny przedmiot Ukryty program szkoły w całości realizowany on-line. Uczestnicy mieli do dyspozycji platformę internetową, dzięki której mogli kontaktować się z prowadzącym oraz ze sobą nawzajem. Na początku zostały im przesłane autorskie materiały:

1) specjalnie przygotowany tekst Ukryty program szkoły i nauczyciela. Informacje podstawowe, w którym scharakteryzowano pojęcie oraz obszary funkcjonowania ukrytego programu w edukacji (szkolna codzienność: przymus, ocenianie, przestrzeń, tłok, rutyna; programy i plany kształcenia, treści nauczania i podręczników, metody i formy nauczania; ukryty program wychowania w szkole; wewnętrzny program nauczycieli) oraz podano zestawy pytań ukierunkowujących analizę omawianych obszarów w odniesieniu do szkoły, w której pracują uczestnicy;

2) cykl zawierający cztery popularnonaukowe artykuły na temat ukrytego programu szkoły i nauczyciela opublikowane wcześniej w „Psychologii w Szkole" (Pankowska, 2008a; 2008b; 2009a; 2009b).

Nauczyciele uczestniczący w szkoleniu mieli wykonać dwa zadania:

- po lekturze tekstów podzielić się swoimi refleksjami na forum dyskusyjnym (i ewentualnie podjąć dyskusję z innymi uczestnikami),

- dokładnie przeanalizować wybrany aspekt (obszar) ukrytego programu w swojej szkole $\mathrm{i}$ - w razie potrzeby - zaproponować działania minimalizujące jego oddziaływanie, a następnie zamieścić opracowanie na platformie, aby było dostępne zarówno dla prowadzącej zajęcia, jak i dla pozostałych uczestników; to zadanie nauczyciele pracujący w tej samej szkole mogli wykonywać w parach.

Wypowiedzi nauczycieli uzyskane w ten sposób stały się materiałem do analizy w niniejszych badaniach.

Grupę badaną zatem stanowili uczestnicy szkolenia - dyplomowani nauczyciele rekrutujący się ze szkół różnego typu (podstawowych, gimnazjów, ponadpodstawowych) z województwa lubelskiego. Wypowiedzi udzieliło 75 osób, z czego 74 kobiety i jeden mężczyzna. Materiał badawczy stanowiło 130 wypowiedzi; jako jednostkę analityczną przyjęto krótszy (refleksja, głos w dyskusji) lub dłuższy (opracowanie), ale odrębny wpis na platformie.

Badania miały charakter jakościowy, co wynikało z zastosowanej metody analizy treści (Babbie, 2007, s. 342-353). Po wstępnym przeglądzie wpisów, 
bardziej dokładną i systematyczną analizę ukierunkowały dwa problemy badawcze:

1. Jakie reakcje nauczycieli na wiedzę o ukrytym programie szkoły ujawniają się w ich wypowiedziach?

2. Jak nauczyciele postrzegają rzeczywistość edukacyjną w swojej szkole w kontekście wiedzy na temat funkcjonowania i konsekwencji różnych aspektów ukrytego programu?

Celem analizy była próba zidentyfikowania postaw nauczycieli wobec krytycznego spojrzenia na szkolną edukację oraz skonfrontowanie różnych aspektów ukrytego programu z realiami szkół, w których pracują badani. W niniejszym tekście, z braku miejsca, ograniczę się do odpowiedzi na pytanie pierwsze.

\section{Reakcje nauczycieli na wiedzę o ukrytym programie szkoły}

Refleksje nauczycieli zamieszczane na forum dyskusyjnym były pierwszymi reakcjami po lekturze tekstów. Wpisy zazwyczaj były dość krótkie (kilkuzdaniowe), ale spontaniczne i nierzadko bardzo emocjonalne. Niektóre z wątków, np. „Kij w mrowisko”, „Demokracja w szkole?”, „Szkoła - samo zło”, „Czy dyscyplina jest zła?", rozwijały się w dyskusje. Wpisy nauczycieli ujawniły, że dla większości uczestników problematyka ukrytego programu szkoły była dotychczas nieznana lub mało znana, a wskazane wcześniej tytuły wątków wzbudzających najwięcej polemicznych wypowiedzi - że przeczytane treści zostały uznane za co najmniej kontrowersyjne.

Wypowiedzi nauczycieli były reakcją przede wszystkim na opisywane w tekstach instytucjonalne cechy szkoły związane z przymusem, tłokiem, rutyną, presją oceniania, asymetrią relacji nauczyciel-uczeń (wyrażającą się zarówno w aranżacji szkolnej przestrzeni, jak i we władzy nauczycieli - nad mową, czasem, aktywnością uczniów), a także na analizę ukrytych przekazów płynących z treści kształcenia i podręczników utrwalających stereotypy i uprzedzenia społeczne. Należy zaznaczyć, że w przesłanych uczestnikom tekstach była głównie zawarta diagnoza sytuacji: wskazanie tych elementów organizacji instytucji i życia szkolnego, które mogą oddziaływać na przekonanie ucznia o własnej podrzędności (Pankowska, 2008a), powodować rozdźwięk między wiedzą szkolną i funkcjonalną oraz skłaniać uczniów do bierności (Pankowska, 2008b), wywoływać poczucie alienacji z uwagi na narzuconą, dominującą wersję kultury i przyczyniać się do utrwalania stereotypów (Pankowska, 2009a). Podkreślały również znaczenie postaw i zachowań nauczycieli wzmacniających bądź osłabiających skutki instytucjonalnego ukrytego programu 
(Pankowska, 2009b). Jednocześnie zwracały uwagę na potencjalność, a nie na nieuchronność negatywnych skutków oddziaływania szkolnej rzeczywistości na postawy uczniów, zawierały przykłady ukazujące możliwość ich ograniczania lub warunki eliminowania (zwłaszcza w odniesieniu do ukrytego programu nauczycieli) i raczej nie przedstawiały jednoznacznych ocen. Z perspektywy akademickiej teksty wydawały się wyważone, skoncentrowane na wyjaśnianiu, a nie na wartościowaniu, zaś w odniesieniu do nauczycieli - dość empatyczne i wskazujące na zrozumienie złożoności uwarunkowań i trudności ich pracy. Okazało się jednak, że z perspektywy nauczycielskiej są dość kontrowersyjne, a ich odbiór - niejednoznaczny.

W wypowiedziach ujawniło się spektrum postaw wobec wiedzy o ukrytym programie. Poza kilkoma wypowiedziami ujawniającymi niezrozumienie problemu, prawdopodobnie wynikające $\mathrm{z}$ powierzchownego bądź jedynie fragmentarycznego zapoznania się z tekstami (które łącznie obejmowały kilkadziesiąt stron), pozostałe można podzielić na kilka kategorii:

1) akceptacja zdawkowa,

2) refleksyjna akceptacja,

3) ambiwalencja - częściowa akceptacja,

4) sprzeciw.

Do pierwszej kategorii zaliczono kilka wypowiedzi bardzo ogólnikowych, które mogły wynikać z niezbyt uważnej lektury lub braku motywacji do podzielenia się bardziej rozbudowanymi uwagami, np.:

Niewątpliwie ukryty program szkoły funkcjonuje przejawiając się w różnych obszarach szkolnej rzeczywistości. Myślę, jednak, że szkoła nie jest jedyną instytucją, w której takie zjawisko występuje. Nie upatrywałabym jednak w tym zjawisku tylko złych stron. Wierzę, że zdecydowanej większości nauczycieli przyświeca zasada, że najważniejsze to nie szkodzić. Ważne jest żeby uświadamiać sobie istnienie ups $^{1}$, po to, aby ograniczać negatywne skutki jego funkcjonowania. $(\mathrm{W} 5)^{2}$

Wypowiedzi zaliczone do drugiej kategorii (refleksyjna akceptacja) świadczą o żywym odbiorze treści, nawet początkowej reakcji sprzeciwu, ale - po głębszej analizie - zaakceptowaniu takiej interpretacji. U niektórych osób lek-

\footnotetext{
${ }^{1}$ Ups/UPS to skrót oznaczający „ukryty program szkoły” często spotykany w wypowiedziach nauczycieli.

${ }^{2} \mathrm{~W}$ nawiasach podaję numer wypowiedzi (W) nadany podczas kodowania danych.
} 
tura tekstów wzbudziła motywacje do autorefleksji, co było głównym celem edukacyjnym tych zajęć:

Jestem świadoma obecności tego zjawiska, jakim jest ukryty program szkoły. Nie byłam jednak świadoma jego skali i wszystkich omówionych „obszarów”. Podobają mi się propozycje zmierzenia się z tym problemem [...]. (W21)

Bardzo lubię czytać teksty, które budzą emocje - a te wzbudziły we mnie dosyć silne i... skrajne. Rzeczywiście, coś w tym jest, jeśli chodzi o „ukryty program nauczania”, ale atmosfera, która ciągle i nieustannie buduje się wokół pracy nauczyciela sprzyja reakcji „znowu mnie krytykują". Taka też była moja pierwsza reakcja. Jednak po chwili refleksji doszłam do wniosku, że z faktami trudno dyskutować. Ukryty program funkcjonuje, a uświadomienie sobie tego pozwala na ograniczenie czynników, które nie sprzyjają ani pracy nauczyciela ani rozwojowi ucznia. (W48)

Moim zdaniem każde nasze działanie zawiera jakiś ukryty program, czy to nauczanie, czy działania wychowawcze czy nasze codzienne kontakty z innymi ludźmi niekoniecznie związanymi ze szkołą. Oddziaływujemy na innych, inni wpływają na nas... Dopóki nie przybiera to niebezpiecznej formy nie należy się aż tak bardzo tego obawiać. Świadomość jednak takiego oddziaływania może być dla nauczyciela pomocą w przygotowywaniu się do pracy i w efekcie w lepszych działaniach. (W17)

Lektura artykułu potwierdziła z całą pewnością funkcjonowanie ukrytego programu szkoły w każdej placówce. Na co dzień, wszyscy, choć doskonale o nim wiedzą, to po prostu o nim nie dyskutują. Nauczycielska społeczność szczególnie nie lubi dyskusji o sztampie i schematach na lekcjach, znudzonej młodzieży, której nie ma czasu niczego odkrywczego zaproponować, bo program goni, matura się zbliża; unikaniu „mądrości” bystrzejszych uczniów, bo lepiej zakończyć lekcję własnym wnioskiem i najlepiej jeszcze podyktować go do zeszytu... I dlatego potrzebna jest ta często krytyczna refleksja czy autorefleksja... Żeby bowiem zacząć zmieniać, trzeba świadomości, że to coś naprawdę istnieje. (W49)

Trzecia postawa, która ujawniła się zarówno w refleksjach na forum dyskusyjnym, jak i w opracowaniach analitycznych uczestników, zawierała pewną 
ambiwalencję odczuć. Wynikała z konfrontacji obrazu szkoły zawartego w literaturze pedagogicznej z realiami konkretnej placówki, w której pewne elementy ukrytego programu występowały, inne zostały wyeliminowane lub ograniczone, bądź niezauważalne były ich negatywne skutki. Nauczyciele zatem zgadzali się jedynie z częścią tez zawartych w przeczytanych artykułach:

Ukryty program szkoły istniał i istnieje, niezależnie od zmian wprowadzanych w programach nauczania i funkcjonowaniu szkoły. O pewnych obszarach pracy szkoły możemy decydować, np. ustawienie ławek, czy dobór metod nauczania, ale tłok na przerwach? Klasy liczące 40 uczniów? Co może zrobić w tej kwestii nauczyciel? Czy można wykluczyć ocenę ucznia przez rówieśników? Będąc w grupie to raczej niemożliwe. Uważam, że w mojej szkole uczeń jest traktowany podmiotowo, przykładowo; uczniowie dbają o wystrój sali, diagnozowane są oczekiwania i zainteresowania uczniów. Młodzież ma wpływ na organizację uroczystości i imprez szkolnych. Z drugiej strony, aby utrzymać dyscyplinę i przygotować uczniów do egzaminów zewnętrznych, pewne zasady pracy i normy zachowania muszą być narzucone i respektowane. (W67)

Rutyna w znaczeniu ujemnym, rozumiana jako wykonywanie jakichś czynności według utartych szablonów jest na pewno zjawiskiem niepokojącym, któremu należy stawić czoło. Pracuję w bardzo dużej szkole, gdyż uczy się w niej około 1000 uczniów i mimo tego [sic!] wydaje mi się, ze dyrekcja i grono - 100 nauczycieli, starają się, by nie było negatywnych skutków rutyny, która dotyka każdego wraz ze zdobytym doświadczeniem zawodowym. (W47)

Najbogatszą pod względem liczby wpisów i najbardziej zróżnicowaną kategorię tworzyły wypowiedzi wyrażające niezgodę na przedstawioną w tekstach interpretację rzeczywistości szkolnej. We wpisach zakwalifikowanych do tej grupy można zauważyć z jednej strony intelektualny opór przed przyjęciem informacji na temat ukrytego programu, z drugiej zaś - emocjonalną postawę obronną.

Aby dokonać dalszej klasyfikacji wypowiedzi zaliczonych do kategorii „sprzeciwu”, odwołałam się do teorii psychologicznych mechanizmów obronnych, które można zdefiniować jako: „wzorzec myśli, uczuć czy zachowań pojawiających się w odpowiedzi na spostrzegane psychiczne zagrożenie, co umożliwia stosującej go osobie uniknąc świadomości konfliktu lub wywołujących lęk idei czy pragnień" (Colman, 2009, s. 378). Przedstawiony niżej po- 
dział reakcji nauczycieli nie jest oczywiście analizą psychologiczną sensu stricto i dotyczy przede wszystkim tzw. obronności percepcyjnej, w której „,bodźce potencjalnie zagrażające, obraźliwe lub nieprzyjemne albo nie są spostrzegane, albo ich percepcja ulega zniekształceniu" (Colman, 2009, s. 457). Jak pokażą przytoczone niżej przykłady, w wypowiedziach nauczycieli znalazło się wiele analogii do reakcji obronnych określanych jako: zaprzeczenie, idealizacja, projekcja, racjonalizacja oraz zachowania agresywno-obronne.

Zaprzeczenie polega m.in. na nieprzyjmowaniu do wiadomości tych aspektów rzeczywistości, które są dla jednostki nieprzyjemne, nieakceptowane czy bolesne (Colman, 2009, s. 891). W wypowiedziach nauczycieli negowanie ustaleń zawartych w literaturze przyjmowało różne formy. Jedną z nich było sprowadzanie wiedzy o różnych aspektach ukrytego programu do jednego wątku w sposób uproszczony (i czasem karykaturalny), a następnie zaprzeczanie jego istnieniu:

Ja również z mieszanymi uczuciami przeczytałam teksty, w których nauczyciel to prawie samo zło, a uczeń biedny, zdominowany i nieporadny. Nie wiem, jak w innych, ale w mojej szkole tak nie jest. (W32)

Uważnie słucham swoich wychowanków, nie ograniczam ich, nie przerywam wypowiedzi, cieszę się jeżeli są aktywni na zajęciach. W mojej szkole nie ma drzwi dla wybranych, korytarze nie są szare i ponure. Uczeń ma obowiązki, ale ma też prawa, które szanujemy. Zgadzam się z przedmówczynią, że ktoś tu uprawia czarnowidztwo. (W35)

Na szczęście dla wszystkich, zarówno nauczycieli, jak i uczniów, taki ponury obraz szkoły będącej autorytarną instytucją, łamiącą charaktery wychowanków należy do przeszłości. (W37)

Szkoła jako instytucja musi opierać się na określonych zasadach, jednak daje uczniom poczucie swobody. Moja placówka, w której uczniowie mają znaczny wpływ zarówno na organizacje życia szkolnego, jak i proces edukacyjny, jest najlepszym tego przykładem. (W40)

Absolutnie nie zgadzam się z tak postawioną tezą, iż szkoła musi mieć drugie dno i musi być ono bagienne. (W51)

Rutyna? W szkole?! (W39) 
Inny wariant zaprzeczania polegał na bagatelizowaniu problemu:

Wydaje się, że owa uczniowska przestrzeń w szkole jest ograniczona, ale nie ma głosów negatywnych na ten temat od uczniów czy ich rodziców. (W3)

W czasie zajęć uczniowie nie przemieszczają się swobodnie po sali, ale sygnalizowanie np. potrzeby podejścia do kosza nie stanowi problemu - pytania są wyrażane w sposób kulturalny, nikt nie manifestuje niechęci wobec obowiązującej zasady, zaś nauczyciele, wychowawcy potrafią docenić starania, wzmocnić pozytywną motywację do dbałości o wspólną przestrzeń pochwałami, podziękowaniem. (W63)

Nie słyszałyśmy narzekań uczniów, czy rodziców, więc chyba z przestrzenią w szkole nie jest tak źle, jak podają naukowcy. (W72)

Uważam, że jeśli jesteśmy świadomi istnienia programu ukrytego szkoły, kontrolujemy go i modyfikujemy w pewien sposób, to nie dzieje się nic złego. (W77)

Kolejnym rodzajem nieprzyjmowania do wiadomości pewnych prawd może być swoiste „odwrócenie problemu”, polegające m.in. na ignorowaniu związków przyczynowo-skutkowych i akceptowaniu wewnętrznej sprzeczności wypowiedzi, np.:

W trakcie lekcji [uczniowie] nie mają możliwości swobodnego przemieszczania się po sali, wyjątkiem są oczywiście zajęcia w grupach, czy wymagające ruchu metody aktywizujące. Zresztą uczniowie nie oczekują, że w czasie lekcji będą mogli swobodnie się poruszać po klasie czy rozmawiać. Przestrzeń w szkole daje uczniowi przekaz, że jest ważny, ale usytuowanie biurka przed ławkami to sygnał, że nauczyciel jest osobą prowadzącą zajęcia, to on narzuca klasie sposób pracy. (W83)

Odmienny sposób radzenia sobie z niewygodną wiedzą przez odwrócenie problemu to sytuowanie się w roli „ofiary” oddziaływania ukrytego programu i przeciwstawianiu swojej (pożałowania godnej!) sytuacji - komfortowej sytuacji uczniów: 
W mojej szkole i uczniowie, i nauczyciele, i inni pracownicy szkoły wchodzą jednym wejściem. Rzeczywiście uczniowie idą do szatni, która poniekąd jest ich azylem, w której „kwitnie” życie towarzyskie i którą uczniowie zaakceptowali bez sprzeciwów. Nauczyciele mają pokój nauczycielski, który jest jednocześnie szatnią, miejscem pracy, miejscem spotkań z rodzicami czy innymi osobami z zewnątrz i w którym tak naprawdę panuje hałas, nie da się odpocząć. [...] Na przerwach uczniowie korzystają z odpoczynku [...] Nauczyciel jest zobligowany do pełnienia dyżuru w określonym miejscu szkoły. (W3)

Wspólnie z koleżanką przeanalizowałyśmy przestrzeń w naszej szkole i jeśli ktokolwiek ma powody narzekać na jej brak, to chyba nauczyciele. Powód? Zajmujemy najmniej miejsca w całej sali - biurko i skrawek podłogi z dostępem do tablicy (naszym zdaniem przedmiotem bardzo praktycznym) po jego jednej stronie, to może $1 / 8$ całej pracowni. Często nawet za nim nie siadamy, bo po prostu nie widzimy uczniów. Tułamy się tak często jak nasi uczniowie, do rzadkości należy własna pracownia z zapleczem, w przeciwieństwie do gimnazjalistów, którzy mają swoje szafki. (W72)

Ten sposób postrzegania rzeczywistości szkolnej, kontrastujący z wymową tekstów na temat ukrytego programu, wiąże się z drugim, występującym w analizowanych wypowiedziach, mechanizmem obronnym, polegającym na idealizacji rzeczywistości szkolnej, a zwłaszcza nauczycieli jako grupy zawodowej.

Program szkolny jest przedmiotem wieloaspektowych analiz, z których wynika tylko jedno: spór co do kształtu szkoły trwa i jest to spór akademicki. Ciągle są jeszcze w środowisku szkolnym właściwi ludzie na właściwych miejscach, którzy czynią swoją powinność w sposób jedynie właściwy. (W68)

Mamy doprawdy wielu cudownych, mądrych nauczycieli, którzy chcą dobrze zarówno dla szkoły i uczniów. I nie przeszkadza im w osiąganiu szczytnego celu nauczania i wychowania żadne ups, nawet bez świadomości istnienia tego ,zjawiska” potrafią dobrze uczyć stosując różne metody pracy dydaktycznej i wychowawczej. (W16)

A tak na poważnie - mam oczywiście świadomość istnienia ukrytego programu szkoły, ale również na każdym kroku czynimy ukłon w stronę ucznia, pamiętamy (lub też przypomina się nam), iż szko- 
ła jest dla uczniów, a nie odwrotnie, dbamy o wszechstronny rozwój uczniów, o to by mieli dostęp do środków audiowizualnych, żeby przekazywane treści były atrakcyjne... stajemy na głowie, żeby uczeń był zadowolony (i dyrekcja również). (W23)

Z pewnością zdarzają się tacy nauczyciele, którzy zapomnieli, komu mają służyć. Szczęśliwym zrządzeniem losu nie było mi dane ich spotkać. (W51)

Oczywiście nie można zaprzeczyć, że jest w Polsce wielu nauczycieli, którzy pokonują liczne bariery (także wynikające z ukrytego programu instytucji i systemu oświatowego), angażują swój czas, energię i emocje, aby skutecznie i z pasją nauczać, wspierać uczniów oraz pomagać im w rozwoju. Jednak w kontekście konfrontacji z ,niewygodną” wiedzą o szkole, wypowiedzi takie można uznać za „wywyższanie” lub „uwznioślanie” obiektu, co jest istotą idealizacji jako reakcji obronnej (Colman, 2009, s. 268).

Mechanizm projekcji polega na rzutowaniu na innych własnych nieakceptowanych uczuć, zachowań, motywów działania, chroniąc się przed obniżeniem samooceny (Kozielecki, 1976, s. 134-135). W nauczycielskich wypowiedziach można odnaleźć pewne symptomy projekcji w przypisywaniu negatywnych zjawisk i zachowań kojarzonych z ukrytym programem, a także odpowiedzialności za jego istnienie innym podmiotom niż sami nauczyciele i/lub szkoła, z którą nauczyciele się identyfikują. Głównym „winnym” okazało się przede wszystkim Ministerstwo Edukacji Narodowej czy - szerzej rozumiane - władze oświatowe:

Ja jednak chciałabym wspomnieć, że przede wszystkim istnieje coś co może być nazwane ukrytym programem MEN-u, dla którego nie jest chyba ważne ani dobro ucznia, ani nauczycieli a jedynie procent obywateli polskich posiadających wykształcenie średnie i papier świadectwa dojrzałości w porównaniu do wyników osiąganych w innych krajach UE. Ponadto, być może to, że istnieje coś takiego jak ukryty program szkoły, czego oczywiście nie neguję, jest reakcją i próbą przetrwania w sytuacji ciągłego majsterkowania przy polskim szkolnictwie, niekończącym się zmianom, które de facto prowadzą do obniżenia poziomu kształcenia, przed którym szkoły bronią się jak mogą i stąd ups. (W8)

UPS w dużej mierze wynika z prozaicznej przyczyny braku funduszy na oświatę, ale również z narzucanego nam z góry systemu naucza- 
nia - mam tu na myśli chociażby przeładowane programy nauczania, które są zmorą zarówno dla uczniów, jak i rozliczanych z ich realizacji za „wszelką cenę” i „,bez względu na wszystko” nauczycieli. (W10)

Ups... mamy rzeczywiście z MEN, które to jest wielokrotnie w sprzeczności z samym sobą, i potrafi nas ciągle czymś zaskakiwać i wprowadzać zupełnie nieprzygotowane reformy. (W16)

Obiektem projekcji stali się w jednej z wypowiedzi młodzi nauczyciele jako grupa przeciwstawiana starszym i bardziej doświadczonym:

Gorzej z młodym pokoleniem nauczycieli, które podchodzi do zawodu konsumpcyjnie. Obserwuję często ich zachowania i to oni powinni się szczegółowo zapoznać z tekstami Pani Doktor oraz dokonać szczegółowej analizy swojej pracy, a zwłaszcza relacji nauczyciel uczeń. (W6)

Wreszcie pośrednio i mnie, jako prowadzącej zajęcia, przypisano tworzenie ukrytego programu: „A tak na marginesie, jaki jest ukryty program tego kursu, skoro uczestnicy ulegają przymusowi dzielenia się refleksjami na Forum?" (W25).

Trudno nie zgodzić się z wypowiedziami, które wskazują na udział władz oświatowych i rozwiązań systemowych w tworzeniu instytucjonalnego ukrytego programu i takich warunków pracy, które zmuszają nauczycieli do transmitowania go w swoich zachowaniach (problem ten był poruszany również w przesłanych uczestnikom tekstach). Jednak przerzucanie odpowiedzialności za istniejący stan na innych, bez uwzględnienia roli własnej bądź konkretnej placówki w funkcjonowaniu systemu, łatwo może wyprzeć ze świadomości potrzebę autorefleksji i podjęcia procesu zmian.

Dużą grupę wypowiedzi można określić jako racjonalizację. Jest to dość pojemny znaczeniowo psychologiczny mechanizm obronny, ponieważ do racjonalizacji zalicza się zarówno uzasadnianie swoich zachowań, motywacji czy uczuć zgodnie z aprobowanymi społecznie normami, przywoływanie fałszywych lub nieadekwatnych do rzeczywistości wyjaśnień nieakceptowanego zachowania, jak również usprawiedliwianie zachowania logicznie brzmiącymi argumentami bądź podkreślanie szlachetnych motywów działania (Kozielecki, 1976, s. 137-140; Colman, 2009, s. 621). W kontekście niniejszych badań do racjonalizacji zakwalifikowano te wypowiedzi, w których, przyznając istnienie w szkolnej rzeczywistości różnych aspektów ukrytego programu szkoły, 
nauczyciele nadawali im społecznie „słuszny” i pożądany sens. W ten sposób unieważniali w jakiś sposób znaczenie problemu, a nawet przedstawiali jako zjawiska korzystne. Najwięcej takich uzasadnień dotyczyło przymusu szkolnego i wiążącej się z nim władzy nauczycieli, których potrzebę wyjaśniano w różny sposób, odwołując się do:

- określonej filozofii wychowania i nauczania:

To prawda, że szkoła jest instytucją hierarchiczną, w której widać wyraźny podział na uczniów i nauczycieli, ale moim zdaniem to nie jest takie złe, wręcz konieczne. [...] W wychowaniu dzieci (czy to w domu czy w szkole) nie ma miejsca na demokrację, co nie znaczy, że uczeń nie może przejawiać swojej inicjatywy. Może, ale jego poczynania muszą być kontrolowane przez nauczyciela. (W33)

A to, że w szkole są ,przymusy” wobec ucznia, to dobrze. Wiemy doskonale, jakie efekty daje bezstresowe wychowanie... (W6)

Chadzamy tymi samymi korytarzami, ale mamy inne prawa, bo wychowanie i uczenie w swej istocie zakłada podporządkowanie. (W37)

- roli nauczyciela w procesie dydaktyczno-wychowawczym:

musimy zdać sobie sprawę, że różnice między nauczycielem a uczniem będą zawsze gdyż wypełniane przez nas obowiązki są zupełnie inne, role niestety nie mogą być zamienione - my musimy nauczać a młodzież powinna zaczerpniętą od nas wiedzę wykorzystać w swoim przyszłym życiu. (W12)

jako organizatorzy procesu nauczania stajemy się kierownikami, którzy muszą uczyć, panować nad dyscypliną i dbać o bezpieczeństwo uczniów oraz wychowywać ich. Połączenie tych wszystkich ról wymaga zachowania pewnych reguł i zasad, inaczej zapanowałby chaos. (W55)

Nauczyciel niewątpliwie powinien być mentorem, a zarazem tym, który steruje procesem dydaktycznym i wychowawczym na lekcji [...]. (W114)

Nie ukrywam, że zirytowały mnie słowa: „zwykle też nauczyciele zakazują swobodnie przemieszczać się po sali”. Otóż zaryzykuje 
stwierdzenie, że o autorytecie nauczyciela świadczy to, czy potrafi zorganizować pracę, czy jest w stanie opanować grupę, kontrolować jej poczynania. (W39)

nauczyciel i uczeń mają inny zakres obowiązków, nauczyciel ocenia, bo musi to zrobić nauczając, a uczeń jest oceniany, tak było zawsze odkąd istnieje szkoła i nie jest to przejaw mojej dominacji tylko jeden z wielu obowiązków nauczyciela. To samo dotyczy też poruszania się po klasie czy szkole. (W95)

- zadania szkoły, jakim jest przygotowanie uczniów do życia w społeczeństwie:

Pamiętajmy jednak, że życie to tłum, tłok, praca a z nią związane - przymus i dyscyplina, wypełnianie odpowiednich ról. Do tego wszystkiego przygotowuje współczesna szkoła, nie pomniejszamy jej wartości i nie odbierajmy tej roli. (W77)

Konieczność podporządkowania się obowiązującym regulaminom też nie jest dla uczniów taka zła, w końcu podejmując prace zawodową też będą musieli spełnić oczekiwane wymagania i funkcjonować w różnych zbiorowościach. (W70)

Żyjąc w społeczności, dziecko - przyszły dorosły nie uniknie przecież odpowiedzialności za swoje postępowanie, będzie musiał kierować się zasadami i normami, przyzwyczaić do zależności, a nawet pewnej rutyny. (W31)

szkoła ma przygotować ucznia do pełnienia różnych ról w życiu, m.in. tego, by potrafili dostosować się do norm społecznych. Można się z tym nie zgadzać, ale taka jest rzeczywistość. (W55)

Atmosfera w szkole nie jest sztucznie wykreowanym tworem, ale odbija zjawiska świata zewnętrznego (wobec szkoły), więc nie da się wyeliminować z niej zjawisk, które w tym świecie istnieją. (W25)

- przekonania o konieczności hierarchii i władzy jako zasady porządku społecznego:

nadmiar demokracji w dużej społeczności niestety prowadzi do chaosu. Ktoś musi mieć władzę, w każdej instytucji obowiązuje ta zasada. 
Relacje między uczniami, nauczycielami i dyrekcją we współczesnej szkole są dość liberalne. Nie dla wszystkich jest już oczywiste okazywanie szacunku kadrze pedagogicznej, zatem dobry ukryty program jest potrzebny. (W1)

Młodzi ludzie muszą funkcjonować w ściśle określonych ramach, gdyż w przeciwnym razie gubią się, a w tak dużej szkole grozi to chaosem. [...] Dyscyplina w szkole jest niezbędna i nie widzę w tym aspekcie żadnego zagrożenia. (W78)

- właściwości uczniów (rozwojowych, wynikających z natury człowieka bądź specyfiki współczesnego młodego pokolenia):

Wprawdzie dzieci nie mają wielkiego wpływu na programy wychowawcze czy programy nauczania, ale jak mogą mieć, skoro nie wiedzą, co jest ważne i istotne, jakie wartości propagować... (W3)

Uczniowie nie mają wpływu na plan lekcji, godziny rozpoczęcia i zakończenia zajęć, program nauczania czy wybór podręcznika. Nie uważam jednak tego za wielki problem - w końcu nie mają kompetencji, aby program nauczania wybrać, a plan lekcji wynika z wielu uwarunkowań (np. podział na grupy, dojazdy). (W98)

Warto również pamiętać, że człowiek jest z natury leniwy i egocentryczny, a nie tylko dobry i miły, jak wierzył J. J. Rousseau. Proces wychowania polega m.in. na wyzwalaniu go z pęt własnego egoizmu i lenistwa. Żad[n]a z metod się jak dotąd nie sprawdziła poza przymusem, począwszy od przymusu mycia zębów, a na przymusie płacenia podatków skończywszy. (W2)

Uczeń potrzebuje jasno określonych zasad, dyscypliny, dostosowania się do reguł. Wcale nie chce decydować o różnych sprawach, potrzebuje autorytetu i ograniczenia jego rozpasanej często wolności. Szkoła bywa dla niego często jedynym miejscem (w sytuacji kryzysu rodziny), w którym stawia się młodemu człowiekowi bariery. Jak można kogokolwiek wychować i czegokolwiek nauczyć bez stosowania minimalnego chociaż systemu opresji. Człowiek to istota leniwa a nauka to ciężka praca, więc bez stosowania minimalnego choćby przymusu nic się nie osiągnie. (W19) 
W dzisiejszej współczesnej szkole coraz trudniej pracuje się z uczniami. Poloniści mają problem ze zmotywowaniem uczniów do czytania lektur. A cóż dopiero jak uczyć bez podręczników, dyscypliny i oceniania? [...] Kolejne nasuwające się pytanie - czy gdyby nie przymus uczęszczania do szkoły, ktokolwiek z młodych ludzi skorzystałby z tego dobrodziejstwa. (W18)

- zapewnienia bezpieczeństwa uczniom jako priorytetu: nauczyciele analizujący szkolną przestrzeń jako jednoznacznie pozytywny fakt przedstawiali monitoring zewnętrzny i wewnętrzny, obecność ochroniarzy, niemożność wyjścia ze szkoły w czasie lekcji czy dyżury nauczycieli podczas przerw, zwykle nie wiążąc takich zjawisk z przymusem szkolnym.

Wypowiedzi nauczycieli racjonalizujące istnienie przymusu szkolnego były dość liczne, a wyrwane z kontekstu szerszych wypowiedzi mogą przedstawiać ich jako autorytarnych, a nawet opresyjnych. Z przeglądu całości materiału wynika jednak, że większość autorów wpisów to zwolennicy uwzględniania potrzeb uczniów i ich wpływu na niektóre, zwłaszcza pozadydaktyczne, aspekty działalności szkoły. Nauczyciele deklarowali otwartość na propozycje wychowanków i negocjowanie zasad przestrzeganych w szkole, a także podawali wiele przykładów realnego wpływu uczniów na wygląd sal i korytarzy, organizację zajęć pozalekcyjnych, kształt szkolnych imprez czy opracowywanie wychowawczych programów klasy. Mimo to z wypowiedzi nauczycieli wynika bardzo silne przywiązanie do adaptacyjnego modelu wychowania i dość konserwatywnego spojrzenia na społeczeństwo, w którym ludzie muszą podporządkować się narzuconym rolom, regułom, zasadom. Niektóre wypowiedzi ujawniły również niezrozumienie istoty demokracji i partnerstwa, kojarząc je $\mathrm{z}$ anarchią i traktując jako antynomię autokratyzmu.

Trudno powiedzieć, jak wielu nauczycieli na co dzień dostrzega sprzeczność swojej postawy z oficjalnie głoszoną filozofią polskiej edukacji, która - formułując jako naczelny cel: wszechstronny rozwój osobowości ucznia, odwołuje się do bardziej liberalnych, a przynajmniej humanistycznych koncepcji wychowania, i w jakim stopniu jest to dla nich dolegliwe. Być może właśnie z taką - adaptacyjno-dyrektywną - organizacją życia szkoły, jaka jest poddawana krytyce przez badaczy ukrytego programu, nauczyciele bardziej identyfikują się niż z filozofią, która ukryty program interpretuje jako zagrożenie dla rozwoju jednostek i społeczeństwa jako całości. Sprzeciw wobec prezentowanych uczestnikom treści byłby zatem przede wszystkim niezgodą na kwestionowanie aprobowanej przez nich wizji edukacji. 
W tym kontekście nie dziwi ujawniająca się kolejna postawa, którą można określić jako reakcję agresywno-obronną. Niektórzy nauczyciele zinterpretowali przedstawione w tekstach analizy ukrytego programu szkoły jako atak na siebie jako grupę zawodową bądź szkołę jako instytucję. Rzeczywistość szkolna opisywana w materiałach pomocniczych nie była wynikiem wielowymiarowej diagnozy polskiej edukacji - w tekstach akcentowano tylko te wątki, które wiążą się z ukrytym programem i jego skutkami. Ich kondensacja mogła jednak spowodować, że obraz szkoły wydał się niektórym uczestnikom - jak pisali - „czarno-biały”, wyolbrzymiony, ponury, pesymistyczny, „zdemonizowany", mimo iż w tekstach wskazywano możliwości zmiany. Z kolei zachęta do analizowania realiów własnej szkoły i weryfikowania ustaleń badaczy była wyraźnym sygnałem, że ukryty program i jego skutki mogą być w jakimś zakresie eliminowane. Jednak część uczestników, czy to z powodu nieuważnej lektury, czy też z innych względów, poczuła się niezasłużenie skrzywdzona i zareagowała obroną przez atak:

Najlepiej za wszystkie niepowodzenia ucznia jak i szkoły obwinia się nauczyciela. (W18)

Wciąż musimy odpierać jakieś zarzuty. Może najwyższy czas dostrzec, jak dbamy o to, aby się doskonalić, pracujemy z pasją. (W74)

Niektóre wypowiedzi zawierały pewną dozę agresji skierowaną wobec różnych adresatów. Pojedyncze dotyczyły uczniów, zarzucając im brak motywacji, lenistwo, bierność czy niechęć do korzystania z ofert szkoły, a także mediów, które kreując negatywny wizerunek nauczycieli, obniżają ich autorytet. Inne wpisy zawierały pretensje wobec władz oświatowych, np.:

Przykre jest też, że Ministerstwo zgadza się na te przemiany [dotyczące egzaminów zewnętrznych], a urzędnicy pracujący tam nie sprawdzają czy np. wydawnictwa już opracowały kolejne podręczniki czy repetytoria do nowych wymagań, ale kogo to interesuje i tak zawsze „oberwie” nauczyciel. (W14)

W jaki sposób uczyć mądrze, ciekawie, twórczo przy obecnym programie nauczania? Jak powiązać niektóre lektury ze współczesnością i problemami młodzieży? [...] Jak zachęcić i przekonać do uczęszczania do szkoły tych, którym i przymus szkolny nie wystarcza? Jak przekształcać przestrzeń klasy, korytarze przy zerowych środkach 
szkoły na te cele? Jak uczyć bez programu, podręcznika, oceniania, dyscyplinowania, jeśli ma się przed sobą trzydziestoosobową klasę „indywidualistów”? (W43)

Najwięcej wypowiedzi z tej grupy skierowanych było w sposób mniej lub bardziej bezpośredni do środowiska akademickiego kreującego określone wizje i interpretacje rzeczywistości edukacyjnej, w tym zapewne i do mnie jako autorki tekstów:

Materiał ten wyzwolił więc lawinę pytań: dlaczego wszystko to, co szkoła wpaja młodym ludziom do niej uczęszczającym, usytuowane poza podstawowymi celami i treściami nauczania, musi być dla nich krzywdzące? Dlaczego jasne zasady postępowania są z góry oceniane negatywnie? Gdzie zagubiło się pojęcie ,autorytetu” (mądrego mistrza, przewodnika) w procesie kształcenia i wychowania? Dlaczego jakakolwiek zaplanowana przez innych aktywność jest od razu odczytywana jako zła i krzywdząca dla dziecka? Dlaczego samo chodzenie do szkoły jest nazywane przykrym obowiązkiem? (W51)

Obraz nauczyciela w tekście nie jest pozytywny i przez to krzywdzący. Aby wykonywać tę pracę, trzeba mieć dużo cierpliwości i samozaparcia. (W28)

na wiele czynników - wspomnianych w artykułach - nie mamy większego lub żadnego wpływu, a najgorsze jest to, że poddani jesteśmy nieustannej krytyce i to nas obarcza się wszelką odpowiedzialnością za „zło” szkoły - a nasza szkoła nie jest aż taka ZŁA. (W77)

W wielu wypowiedziach jako formę pośredniej agresji stosowano ironię:

Mamy iść w ślady Francji i wyrzucić z podręczników część własnej historii, żeby nie obrażać uczuć uczniów? Poza tym już sobie wyobraziłam, jak z uczniami na początku roku szkolnego demokratycznie wyrzucamy wszystkie lektury romantyczne, bo nudne i analizujemy demokratycznie wybrane, ukochane przez uczennice zwłaszcza, romanse typu „Zmierzch” o błyszczących w słońcu wampirach... (W34)

Nie dość że szkoła to samo zło, to jeszcze obraz nauczyciela, jaki wyłania się z tekstu, czyni go krzewicielem tego zła: nauczyciel pozwala zabrać głos, nauczyciel ustala reguły itd. (W60) 
I chyba nie jest tak źle, skoro moi dawni uczniowie zawsze chętnie zaglądają do naszej szkoły i z rozczuleniem wspominają stare dobre czasy, gdy to była ICH szkoła. Mimo, że wchodzili do szatni oddzielnymi drzwiami. (W74)

Szkoła, nauczyciel jawią się tu jako najwięksi wrogowie uczniów, jeśli do tego dołączyć jeszcze rutynę i brak przestrzeni to mamy katastrofę. (W72)

Skoro istnieją ukryte programy, nauczyciele ustalają reguły, według których mają postępować uczniowie - proponuję ZAMKNĄĆ SZKOŁY i przywrócić guwernanctwo! Wtedy zwiększymy przestrzeń, zrezygnujemy z tablicy itp. a nauczyciel znowu będzie szanowany (teraz najłatwiej nim pomiatać). (W62)

W tym miejscu warto wspomnieć, odnosząc się do nieomawianych tu wyników analiz stanowiących odpowiedź na drugi problem badawczy, że w wielu szkołach opisywanych przez uczestników szkolenia wprowadzono rozwiązania, które ograniczają niektóre aspekty ukrytego programu, zmniejszając jego negatywne skutki. A biorąc pod uwagę, że w zasadzie każde ponadstandardowe działanie w szkole (wyjście, wyjazd, impreza, realizacja projektu edukacyjnego, zmiana wystroju itp.) wymaga od nauczycieli dodatkowego czasu i zaangażowania, można zrozumieć ich rozgoryczenie ujawniane w ostatnich cytowanych wpisach.

\section{Podsumowanie}

Celem analizy treści wypowiedzi nauczycieli było zidentyfikowanie różnych reakcji wobec szczególnego sposobu interpretowania szkolnej rzeczywistości, jakim jest badanie ukrytego programu edukacji. Ujęte w ramy klasyfikacyjne sposoby reagowania nie są ani diagnozą postaw środowiska nauczycielskiego, ani nie stanowią podstaw do formułowania wniosków dotyczących dominujących zachowań w kategoriach ilościowych. Wskazują jednak „,pola trudności” związane z doskonaleniem zawodowym nauczycieli, rozumianym szerzej niż rozwijanie praktycznych kompetencji dydaktyczno-wychowawczych. I choć problematyka związana z wiedzą nauczycieli była przedmiotem badań i refleksji teoretycznej w różnych kontekstach (Polak, 1999; Głogowska, 2004; Kawecki, 2004, 2009), to niniejsze badania mogą uwrażliwić akademików szkolących nauczycieli na kilka kwestii. 
Po pierwsze, proces nabywania wiedzy przez nauczycieli nie jest neutralny poznawczo. Silna identyfikacja z zawodem, jaka ujawniła się w ich wypowiedziach, może być barierą dla przyswajania treści, które w jakiś sposób kwestionują system przekonań, doświadczeń i codziennych problemów, tworzących dla nauczycieli ramę odniesienia w postrzeganiu świata. Dlatego krytyczne spojrzenie z zewnątrz na szkołę i grupę zawodową, nawet zobiektywizowane i wyważone, nauczyciele mogą odbierać w kategoriach emocjonalnych, a nie racjonalnych, co prowokuje do reakcji obronnych.

Po drugie, ujawnił się rozdźwięk między wizją szkoły, jaka wyłania się z teorii i badań akademickich, a jej obrazem z perspektywy doświadczeń nauczycieli. To, co dla pedagogów naukowców jest ważne, niekoniecznie musi być tak odbierane przez praktyków. Wynika to nie tylko z samego języka i sposobu opisu rzeczywistości, ale przede wszystkim z odmienności paradygmatów, które leżą u podstaw jej interpretowana. Wydaje się, że ta kwestia mogłaby stać się interesującym przedmiotem dalszych badań.

Po trzecie, analiza wypowiedzi pokazała ,podskórny” dystans nauczycieli do środowiska akademickiego, które może być odbierane jako oderwane od „prawdziwego" życia szkoły i rzeczywistych problemów nauczycieli. A taka postawa nie motywuje do czerpania wiedzy od naukowców teoretyków (być może jest to jeden z powodów nikłego zainteresowania nauczycieli literaturą pedagogiczną, która nie odnosi się bezpośrednio do praktyki).

Uwagi te nasuwają bardzo praktyczny wniosek dla uniwersyteckiego doskonalenia zawodowego nauczycieli: jeśli nie pozna się, nie spróbuje zrozumieć i docenić spojrzenia nauczycieli na szkołę i specyfikę ich pracy, nie skonfrontuje w dialogu odmiennych wizji edukacji zanim zaproponuje się perspektywę teorii akademickich, to dokształcanie nauczycieli może okazać się mało efektywne.

\section{Bibliografia}

Babbie E. (2007), Badania społeczne w praktyce, Wydawnictwo Naukowe PWN, Warszawa. Colman A. M. (2009), Stownik psychologii, Wydawnictwo Naukowe PWN, Warszawa.

Głogowska R. (2004), Teoretyczna wiedza pedagogiczna w praktyce edukacyjnej, Wydawnictwo UJ, Kraków.

Janowski A. (1989), Uczeń w teatrze życia szkolnego, WSiP, Warszawa.

Kawecki I. (2004), Wiedza praktyczna nauczycieli, Impuls, Kraków. 
Kawecki I. (2009), Rzecz o wiedzy nauczycielskiej, Wydawnictwo Naukowe UJ, Kraków.

Kozielecki J. (1976), Koncepcje psychologiczne człowieka, PIW, Warszawa.

Meighan R. (1993), Socjologia edukacji, Edytor, Toruń.

Pankowska D. (2006), Badanie ukrytego programu szkoły w pracy nauczyciela - refleksyjnego praktyka, „Przegląd Badań Edukacyjnych” 2006, nr 2 (3).

Pankowska D. (2008a), Podłoga ważniejsza od ucznia, czyli o ukrytym programie szkoły, „Psychologia w Szkole” 2008, nr 3.

Pankowska D. (2008b), Czego uczeń dowiaduje się w szkole o wiedzy i uczeniu się? Ukryty program szkoły - cz. 2, „Psychologia w Szkole” 2008, nr 4.

Pankowska D. (2009a), Czego uczeń dowiaduje się w szkole o ludziach? Ukryty program szkoty - cz. 3, „Psychologia w Szkole” 2009, nr 1 (21).

Pankowska D. (2009b), Co zrobić z ukrytym programem szkoły - cz. 4, „Psychologia w Szkole" 2009, nr 3 (23).

Polak K. (1999), Indywidualne teorie nauczycieli. Geneza, badanie, kształtowanie, Wydawnictwo UJ, Kraków.

Żłobicki W. (2002), Ukryty program w edukacji. Między niewiedza a manipulacja, Impuls, Kraków.

\section{The teachers versus knowledge of the hidden curriculum of the school}

\section{Summary}

The article The teachers versus knowledge of the hidden curriculum of the school describes the results of the teacher's experiences with the academic view on the school reality. The author, basing on the analysis of the teacher's opinions, identifies their attitudes - reactions to the texts about the hidden aspects of education. She remarks that the different perspectives of theoreticians and experienced persons may be the source of difficulties in university upgrading teacher's qualifications.

Keywords: hidden curriculum of the school, teachers, upgrading teacher's qualifications. 